\title{
THE PROTECTIVE EFFECT OF HUMIC ACID AND COMPOST EXTRACT APPLICATION ON LETTUCE AND ONION GROWN UNDER SALINITY STRESS
}

\author{
El-Hamdi, Kh.H. ; A.A. Mosa ; B.A. Sasi * \\ Soils Department, Faculty of Agriculture, Mansoura University, 35516 Mansoura, Egypt \\ *Corresponding author. Tel.: +201140006535. \\ E-mail address: libiajoozef@yahoo.com
}

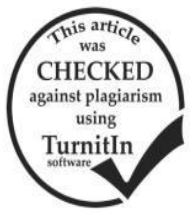

\begin{abstract}
The low productivity of saline water irrigation is the main factor limiting the expansion of their use in agriculture. For this purpose, a pot experiment was conducted outdoor at the Experimental Station of the Faculty of Agriculture, Mansoura University aiming to evaluate the protective effect of humic acid and compost extract (water, EDTA or KOH) application on lettuce (Lactuca sativa L.) and onion (Allium cepa L.) grown under salinity stress in a sandy soil. Saline water irrigation at concentration of $2.1 \mathrm{dS} \mathrm{m}-1$ for lettuce and $1.8 \mathrm{dS} \mathrm{m}-1$ for onion was compared with freshwater irrigation as the control treatment. Results showed that saline water irrigation led to a significant reduction in yield characteristics and NPK concentrations in lettuce and onion as compared with the control treatment. The ameliorative effect of humic acid application led to maximize the investigated parameters as compared with the un-amended treatment. Compost extracts had a protective effect against salinity stress with superiority to EDTA-extracted compost. The combined application of humic acid with EDTA-extracted compost was the optimum treatment for reducing the harmful effect associated with irrigation with saline water resources. Finding from this study suggested that the complementary approach for salinity stress management should be focused on phyllosphere beside rhizosphere.
\end{abstract}

Keywords: Salinity stress; Humic acid; compost extracts; lettuce; onion.

\section{INTRODUCTION}

The per capita share of fresh water resources in Egypt dropped dramatically due to the rapid growth population, and the stable water budget of the River Nile. Secondary water resources, therefore, is progressively being used for agricultural purposes in order to enable freshwater to be used for more economically and socially valuable purposes (Winpenny et al., 2010).

The lower productivity of low quality water supplies (e.g. saline water) is the most limiting factor for expanding in reusing saline water for irrigation. There are various inhibitory effects of salinity on plants grown under these conditions including ion toxicity (e.g. $\mathrm{Na}+$ and $\mathrm{Cl}-$ ), osmotic stress resulted in defects in water uptake, disturbance in the physiological functions in plant cell and nutrients deficiencies in plant (Hasegawa et al. 2000). There is a debate among scientists about the effective defense strategies against salinity stress. Various reports showed that soil amendments application is the most effective strategy to face salinity hazard because of its ameliorating effect for soil physicochemical and biological properties. Others show that research in the physiological properties and the in vivo defense of plants is the operational strategy through working on phyllosphere.

The term humic substances is a general descriptor for a group of organic substances reached the final degradation state, and includes humic acids, fulvic acids, and humin (Stevenson 1982). Through chemical and biological transformation processes, humic substances are formed from plant and animal biomass. Humic substances contribute in various ecological processes e.g. sustaining plant growth and soil microorganisms, regulating soil carbon and nitrogen cycles, improving soil quality parameters and immobilization of various toxic compounds through their sorption effect (Piccolo, 1996). From another point of view, the application of humic substances for soil organic matter management is optimum management practice to face the current environmental challenges of increasing greenhouse $\mathrm{CO} 2$ emissions. Several investigations suggested the beneficial effect of using humic substances in horticultural systems including reducing mineral fertilizers application, increasing fertilizers use efficiency, increasing plant tolerance against environmental stresses, reducing the hazardous effect of plant pathogens, stimulating early growth and maximizing the produced yield (Selim and Mosa 2012; Naidu et al., 2013; Denre et al., 2014).

Compost extracts (common name is compost tea), is a liquid extract of composted materials that contain many growth regulators, plant nutrients and beneficial microorganisms. Compost extracts have been widely used in agriculture since a long time. Compost extracts are now being used in large-scale agriculture, horticulture, residential gardens with different modern technologies to maximize their beneficial effects (Scheuerell and Mahaffee 2002). According to Kone' et al. (2010), compost extracts contain substantial amounts of active functional groups that are able to bind plant nutrients and stimulate beneficial microorganisms (e.g. Pseudomonas sp., Lactobacillus, Trichoderma sp., Penicillium and yeast). Consequently, it is strongly recommended to use these compost extracts with fresh edible plants (e.g. lettuce and onion) instead of conventional pesticides to face pathological injuries.

Lettuce (Lactuca sativa L.) is a major fresh edible plant and its leaves are commonly found in fresh salad mixtures given its number of nutrients and healthpromoting compounds. The nutritional value of lettuce includes its high content of antioxidants, minerals, lipophilic compounds (e.g. chlorophylls and 
carotenoids), minerals, carbohydrates and amino acids (Mou 2009). According to the U.S. Salinity Laboratory in Riverside, lettuce could be considered a moderately salt sensitive crop with a threshold ECe of $1.3 \mathrm{dS} \mathrm{m}-1$ (Ayers et al., 1951).

Onion is considered the most important vegetable crop in Egypt taking into account its high exportation value for European markets. The annual production of onion crop in Egypt is about 1,728,417 $\mathrm{Mg}$ according FAO (FAOSTAT FAO). Although onion is a lowcalories food, it is high in beneficial compounds (e.g. vitamins, antioxidants and minerals). One cup of chopped onion contains about only 64 calories, $15 \mathrm{~g}$ of carbohydrates, no fats or cholesterol, $3 \mathrm{~g}$ of fibers, $7 \mathrm{~g}$ of sugars, $2 \mathrm{~g}$ of proteins and contribute for about $10 \%$ or more from the daily requirements of vitamins. Besides, onion contains substantial amounts and relatively small amounts of $\mathrm{Ca}, \mathrm{Fe}, \mathrm{Mg}, \mathrm{P}$ and $\mathrm{K}$ (Ware 2015). Onion is sensitive to salt stress, and relatively sensitive to ionic stress of $\mathrm{Na}, \mathrm{Cl}-$ and $\mathrm{SO} 42-$, especially at germination stage (Bernstein and Ayers 1953).

The main aim of our research is to find out a complementary approach for increasing lettuce and onion tolerance against salinity stress through working in improving soil quality by humic acid application, and stimulating the induced resistance of both plants against salinity stress by foliar application of compost extracts.

\section{MATERIALS AND METHODS}

A pot experiment was conducted during the winter season of 2014 outdoor at the Experimental Greenhouse of the Faculty of Agriculture, Mansoura University aiming to evaluate the protective effect of humic acid and compost extracts application against salinity stress on lettuce and onion plants grown on a sandy soil.

The used experimental design was split-split plot design. Main plots were assigned to water quality irrigation, which included two treatments (i.e. saline water irrigation at concentration of $2.1 \mathrm{dS} \mathrm{m}-1$ for lettuce and $1.8 \mathrm{dS} \mathrm{m}-1$ for onion as compared with freshwater irrigation as the control treatment). Humic acid applications at rate of $200 \mathrm{mg} \mathrm{kg-1} \mathrm{vs.} \mathrm{the} \mathrm{non-}$ application were assigned in sub plots. In sub-sub plots, compost extracts were applied in three forms: $\mathrm{i}$ foliar application of water-extracted compost, ii foliar application of EDTA-extracted compost and iii foliar application of $\mathrm{KOH}$-extracted compost.

Synthetic saline water was prepared by dissolving natural salt (El-Rashidi) in fresh water according to the required salinity level. The philosophy of using this natural salt instead of $\mathrm{NaCl}$ is to prepare a representative saline water source and to avoid the ionic effect associated with the sole presence of sodium or chloride. Soluble cations and anions analysis of the used commercial salt is illustrated in Table 1.

Table 1: Cation and anion analysis of the used commercial salt

\begin{tabular}{|c|c|c|c|c|c|c|c|}
\hline \multicolumn{4}{|c|}{ Cations (Meq L-1) } & \multicolumn{4}{c|}{ Anions (Meq L-1) } \\
\hline $\mathbf{M g 2}^{+}$ & $\mathbf{C a 2}^{+}$ & $\mathbf{K}^{+}$ & $\mathbf{N a}^{+}$ & $\mathbf{S O 4}^{-2}$ & $\mathbf{C l}^{-}$ & $\mathbf{H C O}^{\mathbf{2}}$ & $\mathbf{C O 3}^{2-}$ \\
\hline 12 & 6 & 4 & 38 & 5 & 40 & 10 & 5 \\
\hline
\end{tabular}

Humic acid was purchased from a private company (Mapon, China) comprising humic acid: $>70 \%$, fulvic acid: $\geq 3 \%$, organic matter: $\geq 85 \%$, moisture: $\leq$ $25 \%, \mathrm{pH}: 4-6$, total NPK $\geq 3 \%$. For preparing compost extracts, $100 \mathrm{~g}$ of composted crop residues was agitated with either, tap water, EDTA $(0.01 \mathrm{M})$ or $\mathrm{KOH}(0.1 \mathrm{M})$ for four $\mathrm{h}$ and filtered.

Soil analyses were carried out according to the standard methods. Particle size distribution was determined using the pipette method as described by Dewis and Fertias (1970). Soil organic matter content was determined by Walkley and Black method described by Hesse (1971). Soil reaction (pH) was measured in soil paste using combined electrode $\mathrm{pH}$ meter as mentioned by Richards (1954). Total soluble salts were determined by measuring the electrical conductivity of soil extract (1 : 2.5) as explained by Jackson (1967). Amounts of water soluble cations $(\mathrm{Ca} 2+, \mathrm{Mg} 2+, \mathrm{Na}+$ and $\mathrm{K}+)$ \& anions (CO32-, HCO3-, Cl- and SO42-) were determined in the soil extract by methods described by Hesse (1971). Available nitrogen in the soil was extracted using $2.0 \mathrm{M}$ $\mathrm{KCl}$ and determined using macro-Kjelahl according to Hesse (1971). Available phosphorus in the soil was extracted with $\mathrm{NaHCO} 30.5 \mathrm{M}$ at $\mathrm{pH} 8.5$ and determined coloromitrically after treating with ammonium molybedate and stannous chloride according to Jackson (1967). Available potassium was determined by extracting soil with $1.0 \mathrm{~N}$ ammonium acetate at $\mathrm{pH} 7.0$ as described by Hesse (1971). Data in Table 2 summarized some physical and chemical analysis of the experimented soil.

All agricultural operations were performed according to the traditional local agriculture management practices. Lettuce and onion (two seedlings) were cultivated in closed plastic pots $(8 \mathrm{~kg})$ in December 17 , 2014. Irrigation was applied to reach the field capacity and the assumed field capacity was readjusted every week. Mineral fertilizers were applied at rates of $60 \mathrm{~kg} \mathrm{~N}$, $15 \mathrm{~kg} \mathrm{P} 2 \mathrm{O} 5$ and $50 \mathrm{~kg} \mathrm{~K} 2 \mathrm{O}$. Plants were harvested in March 21, 2015. After harvesting, fresh weight was recorded to obtain the fresh weight yield. Thereafter, Plant samples were oven dried at 70 until the weight constant, ground using stainless steel equipment and preserved for analysis. To determine concentrations of nutrients in plant tissues, $0.2 \mathrm{~g}$ from each sample was digested using $5 \mathrm{~cm} 3$ from the mixture of sulfuric (H2SO4) and perchloric (HClO4) acids (1:1) as described by Peterburgski (1968). Nitrogen was determined by micro-Kjeldahl method. Phosphorus was determined colorimetrically by spectrophotometer (PG instrumentModel T80) using stannous chloride. Potassium was determined by using Sherwood flame photometer Model M360 as mentioned by Jackson (1967). 
Table 2. Some physical and chemical properties of the experimental soil.

\begin{tabular}{|c|c|c|c|c|c|c|c|c|c|c|c|c|c|c|c|c|c|}
\hline \multirow[t]{2}{*}{ Analyses } & \multicolumn{3}{|c|}{$\begin{array}{c}\text { Particle size } \\
\text { distribution }(\%)\end{array}$} & \multirow{2}{*}{$\begin{array}{c}\mathbf{E C e} \\
\left(\mathbf{d S m}^{-1}\right)\end{array}$} & \multirow[t]{2}{*}{ pH } & \multirow{2}{*}{$\begin{array}{r}\text { O.M } \\
(\%)\end{array}$} & \multicolumn{4}{|c|}{$\begin{array}{c}\text { Soluble anions } \\
\left(\mathrm{Meq} \mathbf{L}^{-1}\right)\end{array}$} & \multicolumn{4}{|c|}{$\begin{array}{l}\text { Soluble anions } \\
\quad\left(\mathrm{Meq} \mathrm{L}^{-1}\right)\end{array}$} & \multicolumn{3}{|c|}{$\begin{array}{c}\text { Available } \\
\text { nutrients }(\%)\end{array}$} \\
\hline & Sand & Silt & Clay & & & & $\overline{\mathrm{CO}_{3}{ }^{2}}$ & ${ }^{2-} \mathrm{HCO}_{3}$ & $\mathrm{Cl}^{-}$ & $\mathrm{SO}_{4}{ }^{2-}$ & $\mathrm{Na}^{+}$ & $\mathbf{K}^{+}$ & $\mathrm{Ca}^{2+}$ & $\mathrm{Mg}^{2+}$ & $\mathbf{N}$ & $\mathbf{P}$ & K \\
\hline Values & 98 & 1.5 & 0.5 & 0.215 & 7.62 & 0.06 & N.D. & 1.2 & 0.13 & 0.39 & 0.75 & 0.05 & 0.52 & 0.40 & 0.03 & 0.16 & 0.01 \\
\hline
\end{tabular}

Statistical analysis at a significance level of (0.05) was performed according to Duncan (1955) using CoStat (Version 6.303, CoHort, USA, 1998-2004).

\section{RESULTS AND DISCUSSION}

Data presented in Table 2 illustrate some physical and chemical properties of the experimented soil. It is cleared that the soil is sandy in texture and very low in colloidal content. In addition, data revealed that soil is very low in fertility with organic matter content of $0.06 \%$ and available nutrients below the sufficient levels for normal plant growth. The soil is not saline given its low colloidal content for ions binding. These results suggested the urgent need for organic matter and fertilizers application to sustain the growth and development of cultivated plants.

Effect of salinity, humic acid and compost extract treatments on fresh and dry weight (g pot-1) of lettuce and onion.

The effect of salinity, humic acid and compost extract treatments on the investigated parameters was significant as shown in Table 3. The shoot fresh weight significantly decreased due to the water salinity effect ( 216 vs. $241 \mathrm{~g}$ pot- 1 in lettuce and 43.8 vs. $49.3 \mathrm{~g}$ pot- 1 in onion for saline and freshwater irrigation, respectively). The same trend was also obvious in shoot dry weight (21.6 vs. 24 g pot-1 in lettuce and 7.4 vs. 9.6 $\mathrm{g}$ pot-1 in onion for saline and freshwater irrigation, respectively).

Several biochemical changes are associated with salinity stress on plants grown under salinity stress. These biochemical changes are related to alterations in leaf proline content, disturbance in malondialdehyde (MDA) formation and lignification in the roots, accumulation in carotenoids and enhanced levels of antioxidative metabolites in root and leaf tissue. Besides, a severe defect in photosynthesis process is occurred due to the damage in cell membrane (Mahmoudi et al., 2011).

Furthermore, the negative effect of salinity on plant water status as a result of the ionic disturbances and the hyper-osmotic stress in plants is one of the principle effects of fresh weight reduction (Ahmad et al. 2010; Azooz et al. 2011). Due to disruption of homeostasis and water imbalance, cell membranes, enzyme activities and photosynthetic processors are affected severely with an over production of reactive oxygen species (ROS) in salt stressed plants. This increment in ROS is responsible for causing oxidative burst as a result of the oxidative damage in plant cells (Ahmad et al., 2011).

Table 3: Fresh and dry weight (g pot-1) of lettuce and onion plants as affected by salinity, humic acid and compost extract treatments.

\begin{tabular}{|c|c|c|c|c|c|}
\hline \multirow{2}{*}{\multicolumn{2}{|c|}{ Treatments }} & \multicolumn{2}{|c|}{$\begin{array}{l}\text { Fresh weight } \\
\text { (g pot-1) }\end{array}$} & \multicolumn{2}{|c|}{$\begin{array}{c}\text { Dry weight } \\
\text { (g pot-1) }\end{array}$} \\
\hline & & Lettuce & Onion & Lettuce & Onion \\
\hline \multicolumn{6}{|c|}{ Salinity treatments effect } \\
\hline \multirow{2}{*}{ Salinity } & Freshwater irrigation & $241 \mathrm{a}$ & $49.3 \mathrm{a}$ & $24 \mathrm{a}$ & $9.6 \mathrm{a}$ \\
\hline & Saline water irrigation & $216 \mathrm{~b}$ & $43.8 \mathrm{~b}$ & $21.6 \mathrm{~b}$ & $7.4 \mathrm{~b}$ \\
\hline \multicolumn{6}{|c|}{ Humic acid treatments effect } \\
\hline \multirow{2}{*}{ Humic acid } & Without humic acid & $215.7 \mathrm{~b}$ & $40.1 \mathrm{~b}$ & $21.6 \mathrm{~b}$ & $7.5 \mathrm{~b}$ \\
\hline & With humic acid & $242.3 \mathrm{a}$ & $53.0 \mathrm{a}$ & $24.0 \mathrm{a}$ & $9.5 \mathrm{a}$ \\
\hline \multicolumn{6}{|c|}{ Compost extract treatments effect } \\
\hline \multirow{3}{*}{ Compost extracts } & Water-extracted compost & $219.5 \mathrm{c}$ & $42.3 \mathrm{c}$ & $21.9 \mathrm{c}$ & $7.7 \mathrm{c}$ \\
\hline & EDTA-extracted compost & $237.0 \mathrm{a}$ & $50.3 \mathrm{a}$ & $23.7 \mathrm{a}$ & $9.3 \mathrm{a}$ \\
\hline & KOH-extracted compost & $230.6 b$ & $47.1 \mathrm{~b}$ & $23.0 \mathrm{~b}$ & $8.5 \mathrm{~b}$ \\
\hline
\end{tabular}

Mean values followed by the same letter within treatments are not significantly different (p< 0.05$)$ according Duncan's multiple range test.

Humic acid exhibited a protective effect against salinity stress as indicated in Table 3 . The protective effect of humic acid against salinity stress increased fresh and dry weight by 11 and $10 \%$ with lettuce $\& 24.3$ and $21 \%$ with onion, respectively as compared with the un-amended treatment. Beside its indirect effect in improving physicochemical and biological properties of saline soils, humic acid has also direct effect on plants grown under saline conditions through its positive effect on the primary metabolism of plant through promoting carbon and nitrogen metabolism. The key enzymes involved in nitrogen metabolism in plant (i.e. nitrate reductase, glutamate dehydrogenase and glutamine synthetas) are stimulated by humic substances under these stress conditions (Albuzio et al., 1986; Muscolo et al., 1999). On the other hand, humic substances have a simulating effect on invertase activity, which favored the hydrolysis of sucrose into hexose as substrate available to growing cells (Schiavon et al., 2010).

Compost extracts have a significant effect on fresh and dry weigh of plants grown under salinity with an obvious superiority for EDTA-extracted compost as 
compared with water- and $\mathrm{KOH}$ - extracted compost (Table 3). KOH-extracted compost ranked the second after EDTA-extracted compost given its high content of potassium. Unlike soil application of compost, most of researches undertaken on compost extracts are normally focus on its protective effect against plant diseases rather than its nutritive impact. In another word, most of these researches are working on phyllosphere rather than rhizosphere. Results of these findings suggested that the suppression of plant pathogens is mainly corresponding to increasing the plant defense pathways in host plants and increasing the diversity and populations of beneficial microorganisms in soil after dropping on the surface layers (Bonanomi et al., 2010). Under abiotic stress conditions (e.g. salinity stress), the induced resistance of plants is normally lower than plants grown under typical conditions. The protective effect of compost extracts appeared on its defense against plant pathogens. There are six proposed mechanisms for the protective effect of compost extracts against plant pathogens: 1- producing antibiotic toxic compounds able to suppress phytopathogens, 2-activating genes responsible for diseases resistance in plants, 3- hyperparasitism of phytopathogens by lytic bacteria and fungi, 4- improving plant nutrition status, which in turn increased plant resistance against diseases, 5- toxicity of active compounds in compost extracts against plant pathogens and 6- improving soil quality properties, which can offer suitable condition for beneficial microorganisms and unsuitable conditions for hazard microorganisms (Mehta et al., 2014).

According to Atta-Ali and El-Beltagy (1992), chelating divalent cations, which EDTA is one of its important materials, are able to bind divalent cations (e.g. $\mathrm{Ca} 2+$ ), which has a vital role in plant nutrition. Recent study also showed that EDTA increased the activity of antioxidant enzymes through decreasing concentrations of malondialdehyde and $\mathrm{H} 2 \mathrm{O} 2$ in root and shoot plant tissues (Ume Habiba et al., 2015). This study also suggested that the beneficial effect of EDTA is associated with its positive effect on gas exchange of plants. Besides, chlorophyll content and net photosynthesis were also improved due to EDTA application. Moreover, EDTA application resulted in activating several antioxidants including (superoxide dismutase, peroxidase, ascorbate peroxidase and catalase). The interactions between irrigation water, humic acid and compost extract treatments and their effects on fresh and dry weight are illustrated in Figs. 1 and 2. The combined treatment of freshwater irrigation with humic acid and EDTA-extracted compost was superior for maximizing fresh and dry weight of lettuce and onion as compared with other treatments, and it is strongly recommended to add humic acid and EDTAextracted compost under saline conditions.

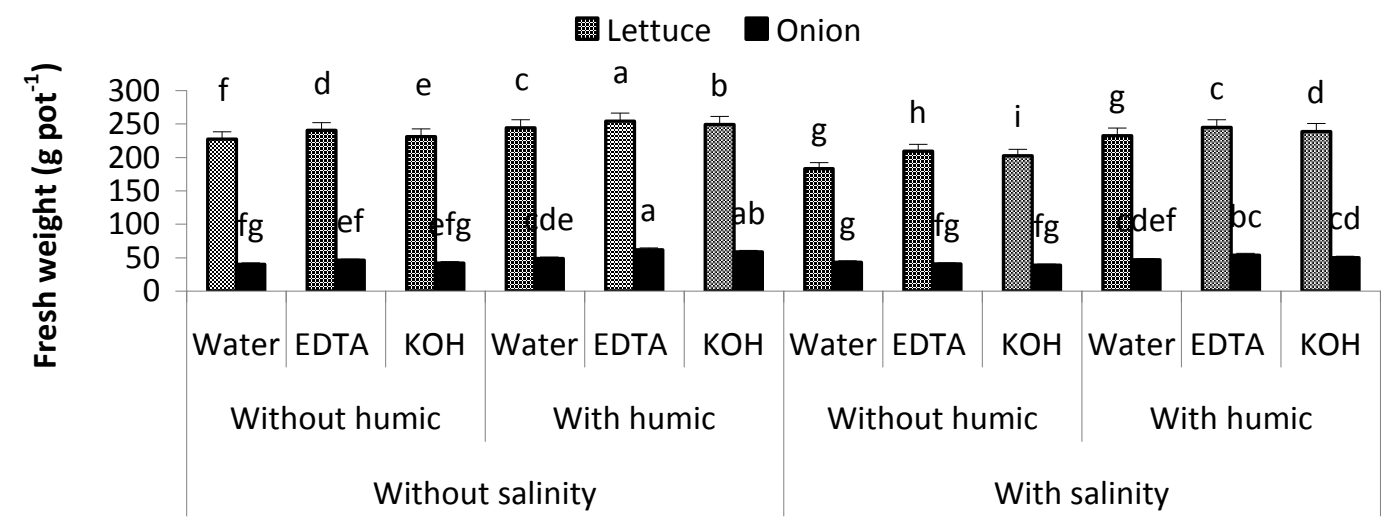

Fig. 1: Effect of interaction between irrigation water quality, humic acid and compost extract treatments on fresh weight of lettuce and onion (g pot-1).

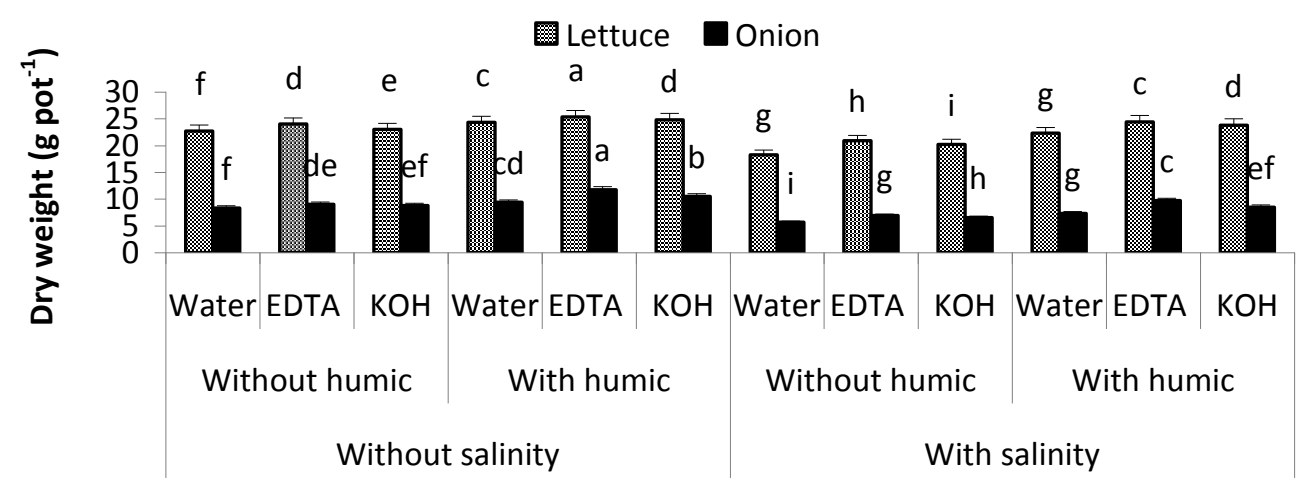

Fig. 2: Effect of interaction between irrigation water quality, humic acid and compost extract treatments on dry weight of lettuce and onion (g pot-1). 
Effect of salinity, humic acid and compost extract treatments on nitrogen, phosphorus and potassium concentration in lettuce and onion.

The effect of water irrigation quality, humic and compost extract application treatments on $\mathrm{N}, \mathrm{P}$ and $\mathrm{K}$ concentration in lettuce and onion plant is illustrated in
Table 4. Data revealed a sharp reduction in NPK concentrations with saline water irrigation. Reductions in lettuce recorded 35.4, 49.2 and $42.1 \%$ for N, P and K, respectively. These reductions, however, were lower in onion with $30.7,41.93$ and $33 \%$ in $\mathrm{N}, \mathrm{P}$ and $\mathrm{K}$, respectively.

Table 4: Nitrogen, phosphorus and potassium concentration (\%) in lettuce and onion plants as affected by salinity, humic acid and compost extract treatments.

\begin{tabular}{|c|c|c|c|c|c|c|c|}
\hline \multirow{2}{*}{\multicolumn{2}{|c|}{ Treatments }} & \multicolumn{2}{|c|}{$\mathbf{N}(\%)$} & \multicolumn{2}{|c|}{$\mathbf{P}(\%)$} & \multicolumn{2}{|c|}{ K (\%) } \\
\hline & & Lettuce & Onion & Lettuce & Onion & Lettuce & Onion \\
\hline \multicolumn{8}{|c|}{ Salinity treatments effect } \\
\hline \multirow{2}{*}{ Salinity } & Freshwater irrigation & $2.60 \mathrm{a}$ & $2.87 \mathrm{a}$ & $0.197 \mathrm{a}$ & $0.217 \mathrm{a}$ & $1.9 \mathrm{a}$ & $2.21 \mathrm{a}$ \\
\hline & Saline water irrigation & $1.68 \mathrm{~b}$ & $1.99 \mathrm{~b}$ & $0.1 \mathrm{~b}$ & $0.126 \mathrm{~b}$ & $1.1 \mathrm{~b}$ & $1.48 \mathrm{~b}$ \\
\hline \multicolumn{8}{|c|}{ Humic acid treatments effect } \\
\hline \multirow{2}{*}{ Humic acid } & Without humic acid & $1.64 \mathrm{~b}$ & $1.96 \mathrm{~b}$ & $0.1 \mathrm{~b}$ & $0.123 \mathrm{~b}$ & $1.0 \mathrm{~b}$ & $1.61 \mathrm{~b}$ \\
\hline & With humic acid & $2.64 \mathrm{a}$ & $2.90 \mathrm{a}$ & $0.2 \mathrm{a}$ & $0.221 \mathrm{a}$ & $2.0 \mathrm{a}$ & $2.08 \mathrm{a}$ \\
\hline \multicolumn{8}{|c|}{ Compost extract treatments effect } \\
\hline \multirow{3}{*}{ Compost extracts } & Water-extracted compost & $1.92 \mathrm{c}$ & $2.42 \mathrm{a}$ & $0.12 \mathrm{c}$ & $0.137 \mathrm{c}$ & $1.3 \mathrm{c}$ & $1.37 \mathrm{c}$ \\
\hline & EDTA-extracted compost & $2.345 \mathrm{a}$ & $2.43 \mathrm{a}$ & $0.18 \mathrm{a}$ & $0.203 \mathrm{a}$ & $1.5 \mathrm{~b}$ & $1.7 \mathrm{~b}$ \\
\hline & KOH-extracted compost & $2.16 b$ & $2.44 \mathrm{a}$ & $0.15 b$ & $0.176 \mathrm{~b}$ & $1.8 \mathrm{a}$ & $2.47 \mathrm{a}$ \\
\hline
\end{tabular}

Mean values followed by the same letter within treatments are not significantly different (p< 0.05$)$ according Duncan's multiple range test.

According to Zhu (2001), the unusual increase in $\mathrm{Na}+, \mathrm{Cl}-$ or SO 4 uptake by plants exposed to high salinity stress tend to decrease the uptake of essential plant nutrients (e.g. NO3-/NH4, H2PO4-, Ca2+ or K+). The gradual reduction in nitrogen uptake by plants could be occurred due to possible antagonism between $\mathrm{Na}+$ and NH4, also between $\mathrm{Cl}-$ and NO3-. Not only ions uptake are negatively affected by salinity stress, but also the protein synthesis, which require $\mathrm{K}$ concentration between 100 and $150 \mathrm{mM}$. However, these required $\mathrm{K}+$ amount could be inhibited by $\mathrm{Na}+$ concentration of $100 \mathrm{mM}$ through the competition between $\mathrm{Na}+$ and $\mathrm{K}+$ given the inability of plants to distinguish between sodium and potassium because of similarity between hydrated radii of $\mathrm{Na}+$ and $\mathrm{K}+$ (Rozeff 1995). Phosphorus availability is also reduced under salinity stress because of some reasons including: $i$ ionic strength effects that reduced the activity of phosphate, ii the low solubility of Ca-P minerals under high $\mathrm{pH}$ value, which associated with high salinity contents and iii the reduction in the redox potentials of nutrient ions under high salinity stress (Qadir and Schubert 2002)

Humic acid resulted in an ameliorative effect against salinity stress. This effect is clearly pronounced in the higher concentrations of N,P and $\mathrm{K}$ as compared with the un-amended treatment. Nardi et al. (2000) recorded a significant increase (about 89\%) in nitrate uptake induced by humic substances as compared with un-amended treatments. From another point of view, Jannin et al. (2012) studied the promoting effect of humic substances through their potential effect on BnNRT1.1 and BnNRT2.1 (genes encoding nitrate transporters) using q-PCR analysis for the expression on Brassica napus. Results of this gene-research investigation showed that humic substances stimulated these genes, which in turn, correlated with activating nitrate uptake. Humic substances have also another positive effect for increasing phosphorus availability under stress conditions through the competition between humic substances and phosphorus on active adsorption sites on soil leading to influx available phosphorus from soil (Guppy et al., 2005). Besides, the acidification effect of humic acid might contribute in increasing the solubility of fixed phosphorus stock in soil as it contain substantial amounts of active functional groups (e.g. hydroxyl and carboxyl), which might serve as a proton donor resulting in lowering soil $\mathrm{pH}$. Above all, the ameliorating effect of humic substances to soil physical, chemical and biological properties could improve the root architecture system and improve the phosphorus uptake by plant roots.

Concerning the effect of compost extracts on NPK concentrations, data revealed that these extracts had a protective effect against salinity stress, which was pronounced in maximizing the plant survival toward nutrients uptake under these abnormal conditions. In this respect, EDTA-extracted compost was the superior treatment for increasing nitrogen and phosphorus uptake. However, KOH-extracted compost was the superior regarding potassium uptake. Beside its vital role as a plant defense against pathogens, no one can deny that compost extracts contain minors of plant nutrients, especially potassium. Moreover, the dissolved organic compounds, which contain substantial amounts of active functional groups, are able to chelate divalent cations (e.g. $\mathrm{Ca} 2+, \mathrm{Mg} 2+$ and $\mathrm{Cu} 2+$ ), thus increase their availability for plant. In addition, compost extract contains considerable concentrations of dissolved organic nitrogen and carbon compounds, which are available for plant uptake (Roberts and Jones 2012). Concerning the interaction effect between treatments, it is cleared that the combined application of humic acid with EDTA-extracted compost was the optimum 
treatment for increasing nitrogen and phosphorus concentrations (either under freshwater or saline water irrigation). This superiority on potassium concentration was obvious under the combined application of humic acid and $\mathrm{KOH}$-extracted compost under both irrigation treatments taking into account the higher content of potassium in $\mathrm{KOH}$-extract.

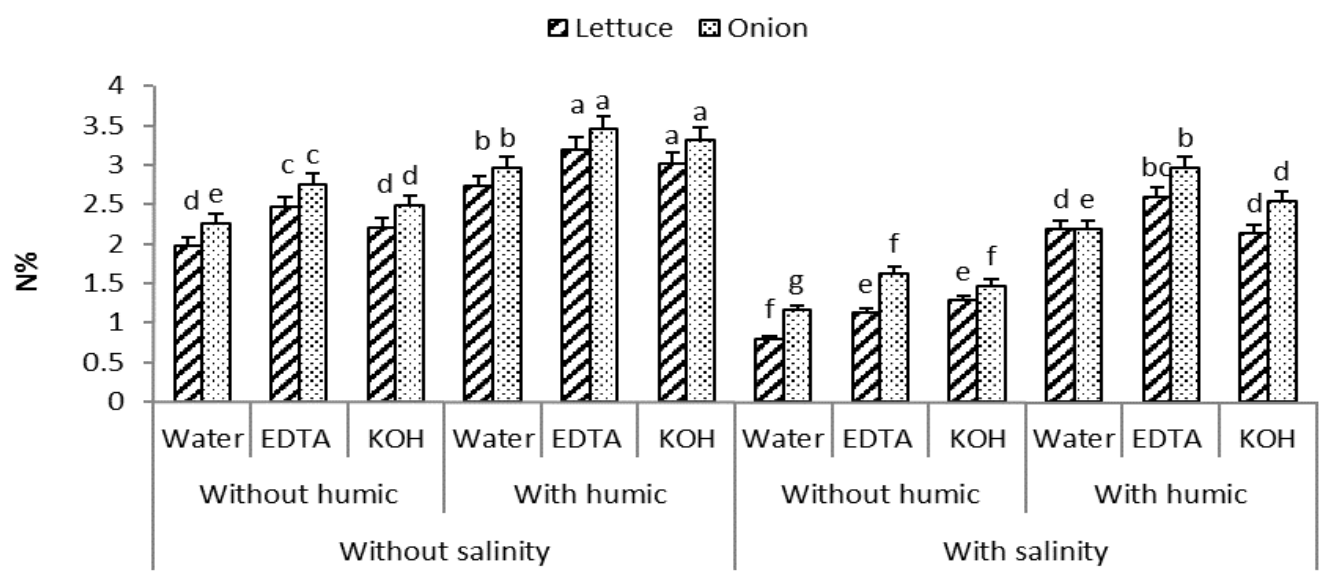

Fig. 3: Effect of interaction between irrigation water quality, humic acid and compost extract treatments on nitrogen concentration $(\%)$ in lettuce and onion.

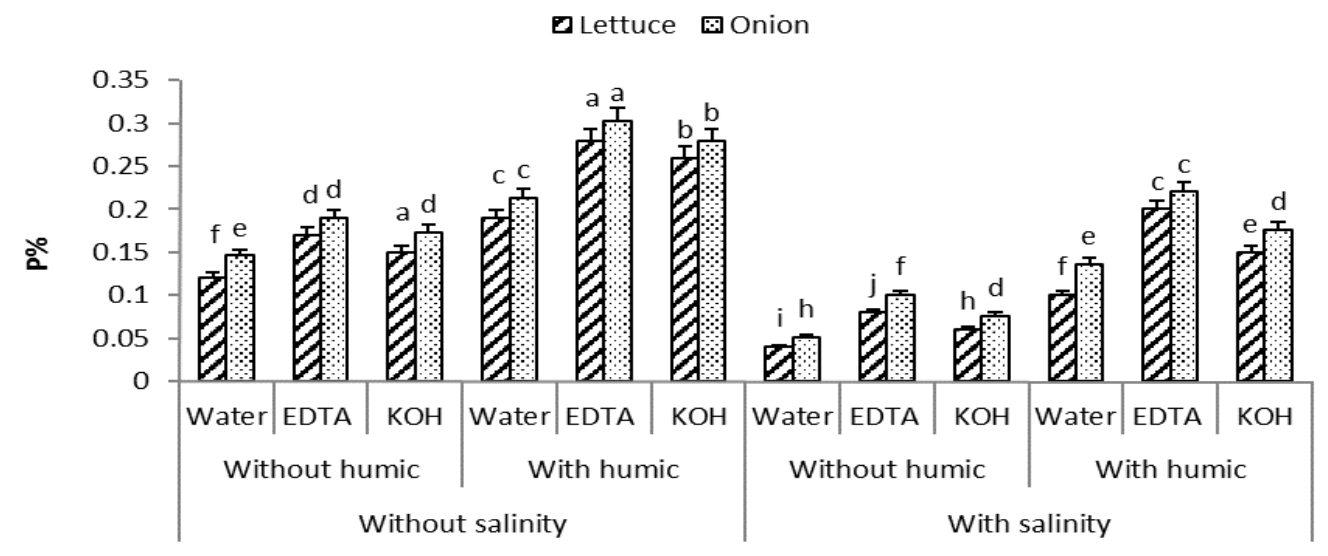

Fig. 4: Effect of interaction between irrigation water quality, humic acid and compost extract treatments on phosphorus concentration $(\%)$ in lettuce and onion.

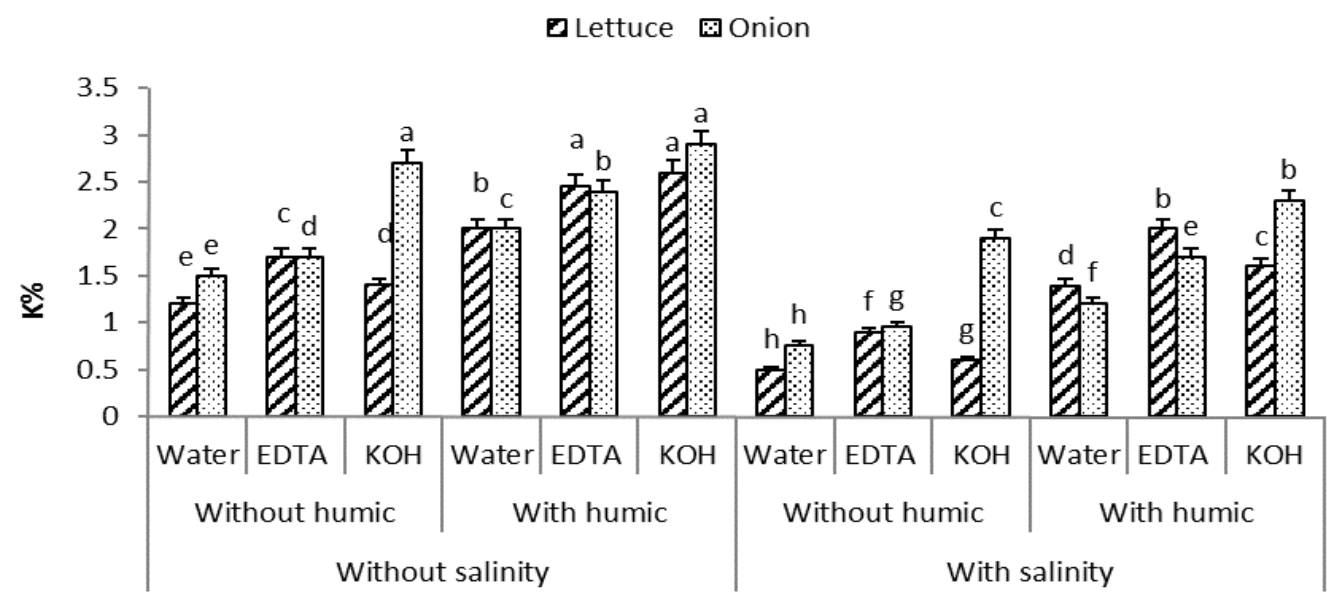

Fig. 5: Effect of interaction between irrigation water quality, humic acid and compost extract treatments on potassium concentration in lettuce and onion (\%) 


\section{REFERENCES}

Ahmad, P., Jaleel, C.A., Salem, M.A., Nabi, G. and Sharma, S. (2010). Roles of enzymatic and nonenzymatic antioxidants in plants during abiotic stress. Crit. Rev. Biotechnol. 30(3), 161-175

Ahmad, P., Nabi, G., Jeleel, C.A. and Umar, S. (2011). Free radical production, oxidative damage and antioxidant defense mechanisms in plants under abiotic stress. In: Ahmad P, Umar S (eds) Oxidative stress: role of antioxidants in Plants. Studium Press, New Delhi, pp 19-53.

Albuzio, A., Ferrari, G. and Nardi, S. (1986). Effects of humic substances on nitrateuptake and assimilation in barley seedlings. Can. J. Soil Sci. 66, 731-736.

Atta-Ali, M. and El-Beltagy, A. (1992). Effect of the cationic chelator EDTA on the ripening of normal tomato fruit and the non-ripening mutants nor, rin and Nr. Postharvest. Biol. Technol. 1, 283-293.

Ayers, A.D., Wadleigh, C.H. and Bernstein, L. (1951). Salt tolerance of six varieties of lettuce. Proc. Am. Soc. Hort. Sci. 57, 237-242.

Azooz, M.M., Youssef, A.M. and Ahmad, P. (2011). Evaluation of salicylic acid (SA) application on growth, osmotic solutes and antioxidant enzyme activities on broad bean seedlings grown under diluted seawater. Inter. J. Plant Physiol. Biochem. 3, 253-264.

Bernstein, L. and Ayers, A.D. (1953). Salt tolerance of five varieties of onions. Proc. Am. Soc. Hort. Sci. 62, 367-370.

Bonanomi, G., Antignani, V., Capodilupo, M. and Scala, F. (2010). Identifying the characteristics of organic soil amendments that suppress soil borne plant diseases. Soil Biol. Biochem. 42 (2), 136-144.

Denre, M., Ghanti, G. and Sarkar, K. (2014). Effect of humic acids application on accumulation of mineral nutrition and pungency in garlic (Allium sativum L.). Int. J. Biotech. Mol. Biol. Res. 5, 7-12.

Dewis, J. and Fertias, F. (1970). Physical and Chemical Methods of Soil and Water Analysis. Soils Bulletin No. 10. FAO. Rome.

Duncan, D. B. (1955). Multiple range and multiple Ftest. Biometrics, 11, 1-42.

FAOSTAT(2010).http://faostat.fao.org/site/567/Desktop Default.aspx?PageID $=567$

Guppy, C.N., Menzies, N.W., Moody, P.W. and Blamey, F.P.C. (2005). Competitive sorption reactions between phosphorus and organic matter in soil: A review. Aust. J. Soil Res. 43, 189-202.

Hasegawa, P.M., Bressan, R.A, Zhu, J.K and Bohnert, H.J. (2000). Plant cellular and molecular responses to high salinity. Annu. Rev. Plant Physiol. Mol. Biol. 51, 463-499.

Hesse, P.R. (1971). A Text Book of Soil Chemical Analysis. Juan Murry (Publisher) Ltd, London.

Jackson, M. L. (1967). Soil Chemical Analysis. Printice-Hall of India, New Delhi.
Jannin, L., Arkoun, M., Ourry, A., Laîné, P., Goux, D., Garnica, M., Fuente, s, M., San,F., rancisco, S., Baigorri, R., Cruz, F., Houdusse, F., GarciaMina, J.-M., Yvin, J.-C. and Etienne, P. (2012). Microarray analysis of humic acid effects on Brassica napus growth: involvement of N, C and S metabolisms. Plant Soil 359, 297-319.

Kone', S.B., Dionne, A., Tweddell, R.J., Antoun, H. and Avis, T.J. (2010). Suppressive effect of nonaerated compost teas on foliar fungal pathogens of tomato. Biol Control 52, 167-173.

Mehta, C., Palni, U., Franke-Whittle, I. and Sharma, A. (2014) Compost: its role, mechanism and impact on reducing soil-borne plant diseases. Waste Manag. 34(3), 607-622.

Mahmoudi, H., Kaddour, R., Huang J. Nasri, N., Olfa, B. T., M'Rah, S., Hannoufa, A., Lachaal, M. and Ouerghi, Z. (2011). Varied tolerance to $\mathrm{NaCl}$ salinity is related to biochemical changes in two contrasting lettuce genotypes. Acta Physiol. Plant 33, 1613-1622.

Mou, B., (2009). Nutrient content of lettuce and its improvement. Curr. Nutr. FoodSci. 5, 242-248.

Muscolo, A., Bovalo, F., Giomfriddo, F. and Nardi, S. (1999). Earthworm humi matterproduces auxinlike on Daucus carota cell growth and nitrate metabolism. Soil Biol. Biochem. 31, 1303-1311.

Nardi, S., Pizzeghello, D., Gessa, C., Ferrarese, L., Trainotti, L. and Casadoro, G. (2000). Alow molecular weight humic fraction on nitrate uptake and protein synthesis in maize seedlings. Soil Biol. Biochem. 32, 415-419.

Naidu, Y., Meon, S. and Siddiqui, Y. (2013). Foliar application of microbial-enriched compost tea enhances growth, yield and quality of muskmelon (Cucumis melo L.) cultivated under fertigation system. Sci. Hortic. 159, 33-40.

Peterburgski, A.V. (1968). Handbook of Agronomic Chemistry. Kolop Publishing House, Moscow, Russia.

Piccolo, A. (1996). Humus and soil conservation. In: Piccolo, A. (Ed.), In humicsubstances in terrestrial ecosystems. Elsevier, Amsterdam, The Netherlands, pp. 225-264.

Qadir, M. and Schubert, S. (2002). Degradation processes and nutrient constraints in sodic soils. Land Degrad. Dev. 13:275-294.

Richards, L.A. (1954). Diagnosis and improving of Saline and Alkaline Soils. U. S., Salinity Laboratory Staff. Agric. Handbook, No.60.

Roberts, P. and Jones, D.L. (2012). Microbial and plant uptake of free amino sugars in grassland soils. Soil Biol. Biochem. 49, 139-149.

Rozeff N. (1995). Sugarcane and salinity-a review paper. Sugarcane 5:8-19.

Scheuerell, S.J. and Mahaffee, W.F. (2002) Compost tea: principles and prospects for plant disease control. Compost Sci. Util. 10, 313-338. 
Schiavon, M., Pizzeghello, D., Muscolo, A., Vaccaro, S., Francioso, O. and Nardi, S. (2010). High molecular size humic substances enhance phenylpropanoid metabolism in maize (Zea mays L.). J. Chem. Ecol. 36, 662-669.

Selim, E.-M. and Mosa, A.A. (2012). Fertigation of humic substances improves yield andquality of broccoli and nutrient retention in a sandy soil. $\mathbf{J}$. Plant Nutr. Soil Sci.175, 273-281.

Stevenson, F.J. (1982). Humus chemistry: genesis, composition, reactions. Wiley-Inter-Science, NewYork.
Ume Habiba, Ali, S., Farid, M., Shakoor, M.B., Rizwan, M., Ibrahim, M., Abbasi, G. H., Hayat, T. and Ali, B. (2015). EDTA enhanced plant growth, antioxidant defense system, and phytoextraction of copper by Brassica napus L. Environ. Sci. Pollut. Res. 22,1534-1544.

Ware, M. (2015). Onions: Health Benefits, Nutritional Information.http://www.medicalnewstoday.com/a rticles/276714.php.

Winpenny, J., Heinz, I., Koo-Oshima, S., Salgot, M., Collado, J., Hernandez, F. and Torricelli, F. (2010). The wealth of waste: The Economic of Wastewater Use in Agriculture Paper No 35. FAO, Rome.

Zhu, J.K. (2001). Plant salt tolerance. Trends Plant Sci. 6, 66-71.

\footnotetext{
التأثير الوقائي لإضافة لحمض الهيوميك ومستخلص الكومبوست علي نباتي الخس والبصل الناميان تحت إجهاد الملوحة التائرة

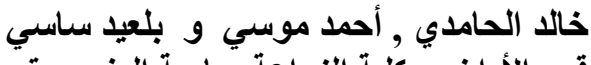

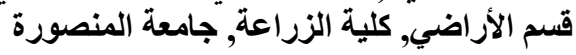

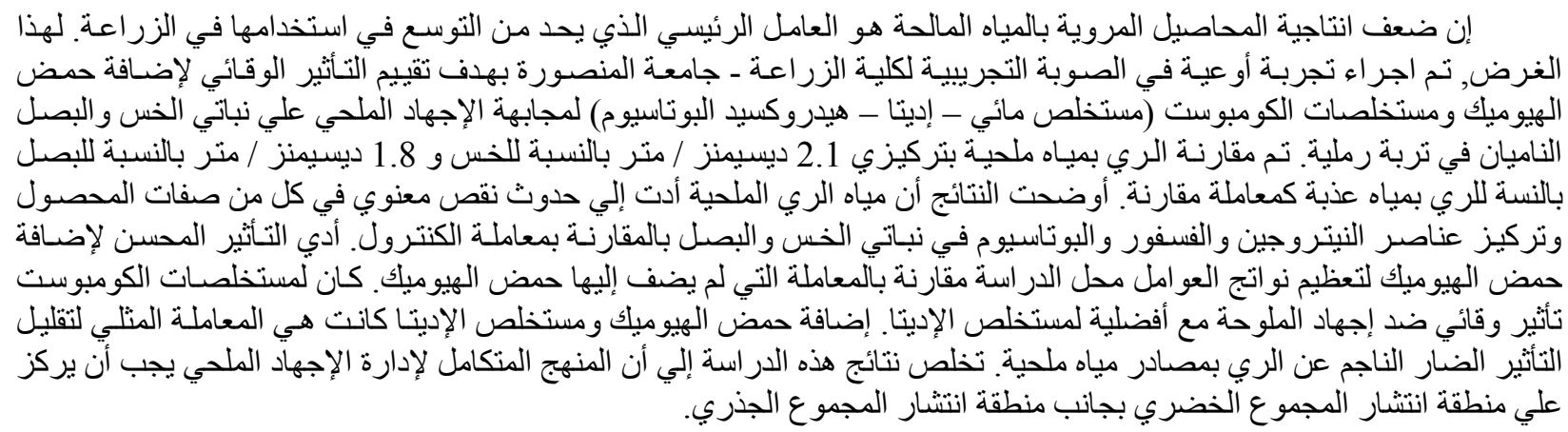

